\title{
Umbilical Cord Blood-Derived Stem Cells Improve Heat Tolerance and Hypothalamic Damage in Heat Stressed Mice
}

\author{
Ling-Shu Tseng, ${ }^{1}$ Sheng-Hsien Chen, ${ }^{2,3,4}$ Mao-Tsun Lin, ${ }^{2,4}$ and Ying-Chu Lin ${ }^{1}$ \\ ${ }^{1}$ School of Dentistry, Kaohsiung Medical University, Kaohsiung City 807, Taiwan \\ ${ }^{2}$ Department of Medical Research, Chi Mei Medical Center, Tainan City 710, Taiwan \\ ${ }^{3}$ Da-An Women and Children Hospital, Tainan City 710, Taiwan \\ ${ }^{4}$ Department of Biotechnology, Southern Taiwan University of Science and Technology, Tainan City 710, Taiwan
}

Correspondence should be addressed to Mao-Tsun Lin; 891201@mail.chimei.org.tw and Ying-Chu Lin; chulin@cc.kmu.edu.tw

Received 13 November 2013; Revised 7 February 2014; Accepted 18 March 2014; Published 7 April 2014

Academic Editor: Nevena Radonjic

Copyright (C) 2014 Ling-Shu Tseng et al. This is an open access article distributed under the Creative Commons Attribution License, which permits unrestricted use, distribution, and reproduction in any medium, provided the original work is properly cited.

\begin{abstract}
Heatstroke is characterized by excessive hyperthermia associated with systemic inflammatory responses, which leads to multiple organ failure, in which brain disorders predominate. This definition can be almost fulfilled by a mouse model of heatstroke used in the present study. Unanesthetized mice were exposed to whole body heating $\left(41.2^{\circ} \mathrm{C}\right.$ for 1 hour $)$ and then returned to room temperature $\left(26^{\circ} \mathrm{C}\right)$ for recovery. Immediately after termination of whole body heating, heated mice displayed excessive hyperthermia (body core temperature $\sim 42.5^{\circ} \mathrm{C}$ ). Four hours after termination of heat stress, heated mice displayed (i) systemic inflammation; (ii) ischemic, hypoxic, and oxidative damage to the hypothalamus; (iii) hypothalamo-pituitary-adrenocortical axis impairment (reflected by plasma levels of both adrenocorticotrophic-hormone and corticosterone); (iv) decreased fractional survival; and (v) thermoregulatory deficits (e.g., they became hypothermia when they were exposed to room temperature). These heatstroke reactions can be significantly attenuated by human umbilical cord blood-derived CD $34^{+}$cells therapy. Our data suggest that human umbilical cord blood-derived stem cells therapy may improve outcomes of heatstroke in mice by reducing systemic inflammation as well as hypothalamo-pituitary-adrenocortical axis impairment.
\end{abstract}

\section{Introduction}

Heat exposure causes an increase in c-fos mRNA and protein in different brain regions including the hypothalamus [1]. Large releases have been reported in brain norepinephrine [2], dopamine, serotonin [3], and glutamate [4]. In addition, heat stress causes the increase in hypothalamic numbers of c-fos-positive cells $[5,6]$ as well as the increase in blood concentrations of both adrenocorticotrophic-hormone (ACTH) and corticosterone [7, 8], suggesting mobilization of the hypothalamic-pituitary-adrenocortical (HPA) axis. According to the findings of Michel et al. [9], intolerance to heat exposure is associated with HPA axis impairment.

Human umbilical cord blood cells (HUCBC) have emerged as an alternative to bone marrow since they have greater availability, lower risk of mediating viral transmission, and weaker immunogenicity [10]. It has also been documented that transplantation of HUCBC is a promising therapeutic strategy against stroke, traumatic brain injury, spinal cord injury, and heatstroke [11-14]. Although we have demonstrated that HUCBC therapy resuscitates heatstroke rats (under anesthesia) by reducing hypothalamic apoptosis [15], evidence is not available about the protective effect of HUCBC-derived CD $34^{+}$cells against the heat intolerance, systemic inflammation, HPA axis impairment, and ischemic and oxidation damage to the hypothalamus in unanesthetized mice under heat stress.

To deal with the hypothesis, in the present study, heat tolerance was evaluated by assessing occurrence of thermoregulatory deficit as well as lethality after heat exposure $[16,17]$. HPA axis impairment was reflected by the plasma levels of both ACTH and corticosterone in response to heat stress [9]. In addition, hypothalamic levels of cellular ischemia markers (e.g., cerebral blood flow [CBF], glutamate, and lactate/pyruvate ratio), oxidative damage indicators (e.g., malondialdehyde [MDA], oxidative- and reduced- form glutathione [GSH and GSSG], glutathione peroxidase [GP ${ }_{x}$, glutathione reductase $[\mathrm{GR}]$, nitric oxide $\left[\mathrm{NO}_{x}{ }^{-}\right]$, and $2,3-$ 
dihydroxybenzic acid [2,3-DHBA]), and plasma levels of inflammatory indicators (e.g., tumor necrosis factor- $\alpha$ [TNF$\alpha$ ], interleukin-10 [IL-10], and ICAM-1) in heat stressed mice treated with $\mathrm{CD}_{3}{ }^{+}$cells or vehicle were assessed [18].

\section{Material and Methods}

2.1. Human CD $34^{+}$Cell Preparation. Human $\mathrm{CD} 34^{+}$cells were isolated from the cord blood of 15 females after informed consent from the mother and IRB approval. Single-cell suspensions of $1 \times 10^{5} / 0.3 \mathrm{~mL}$ of HUCBC were administered via the tail vein immediately after the termination of whole body heating $(\mathrm{WBH})$. All protocols were approved by the Animal Ethics Committee of the Chi Mei Medical Center (Tainan, Taiwan) in accordance with the Guide for the Care and Use of Laboratory Animals of the National Science Council and the Guidelines of the Animal Welfare Act.

Human $\mathrm{CD}_{3}{ }^{+}$cells were isolated from cord blood using a Direct CD34 ${ }^{+}$Progenitor Cell Isolation kit (Miltenyi Biotec, Bergisch Gladack, Germany) and CD34 ${ }^{+}$Multisort kit (Miltenyi Biotec) according to the manufacturer's protocol. In brief, human cord blood lymphocytes and monocytes were suspended in $300 \mu \mathrm{L}$ of phosphate buffered saline (PBS) and $5 \mathrm{mM}$ EDTA. These cells were labeled with a haptenconjugated monoclonal antibody against CD34 (PharMingen, San Diego, CA), followed by an antihapten antibody coupled with microbeads, and were incubated with beads at ratios of $100 \mu \mathrm{L}$ of beads per $10^{8}$ cells for $15 \mathrm{~min}$ at $4^{\circ} \mathrm{C}$. FACS analysis using anti-CD34 antibodies (Phar Mingen) labeled with phycoerythrin (Becton Dickinson, Mountain View, CA) of MACS-sorted cells showed that $96 \pm 3 \%$ of the selected cells were positive for CD34.

2.2. Murine Model of Heatstroke. ICR (Institute of Cancer Research) of the National Institutes of Health in the USA mice were purchased from the National Animal Center (Taipei, Taiwan) and kept under a $12 \mathrm{~h}$ light-dark cycle at controlled temperature $\left(22 \pm 2^{\circ} \mathrm{C}\right)$ with free access to food and tap water: ICR male mice 8 - to 10 - week-old were exposed to $\mathrm{WBH}\left(41.2^{\circ} \mathrm{C}\right.$, relative humidity $50 \%-55 \%$, and for 1 hour) in an environmental temperature-controlled chamber $[16,17,19]$. The heated mice were returned to the normal room temperature $\left(26^{\circ} \mathrm{C}\right)$ after the end of $\mathrm{WBH}$. Mice that survived to day 4 of $\mathrm{WBH}$ were considered survivals, and the data were used for analysis of the results. In separate experiments, $4 \mathrm{~h}$ following $\mathrm{WBH}$, all of the animals were killed and their organs were removed for histological and biochemical evaluation. The contents of $\mathrm{NO}_{x}{ }^{-}, 2,3-\mathrm{DHBA}$, glutamate, lactate-to-pyruvate ratio, glycerol, MDA, GSSG, $\mathrm{GSH}, \mathrm{GP}_{x}$ and GR, and number of neuronal damage scores in the hypothalamus were determined. In addition, systemic inflammatory responses molecules in the peripheral blood stream were assessed. For rectal temperature measurements, unrestrained, unanesthetized mice were used and measurements were collapsed into 10 min averages, taking one mouse each form each group and changing the sequence thereafter. Rectal temperatures were measured by a thermocouple probe (Bailey Instruments, Saddlebrook, NJ, USA).
2.3. Assessment of Thermoregulatory Function. Immediately after the termination of $\mathrm{WBH}$, the animals were returned to a room temperature of $26^{\circ} \mathrm{C}$ for recovery. According to the findings of Chatterjee et al. $[16,17]$, WBH-treated mice became hypothermia, when they were exposed to room temperature $\left(24^{\circ} \mathrm{C}\right)$.

2.4. Neuronal Damage Score. At the end of the experiments, animals were killed by an overdose of sodium pentobarbital, and the brains were fixed in situ and left in skull in $100 \%$ neutral-buffered formalin for at least 24 hours before removal from the skull. The brain was removed and embedded in paraffin blocks. Serial sections (10 $\mu \mathrm{m}$ thick) through the hypothalamus were stained with hematoxylin and eosin for microscopic examination. The extent of neuronal damage was scored on a scale of 1 to 3 , modified from the grading system of Pulsinelli et al. [20], in which 0 is normal, 1 indicates approximately $30 \%$ of the neurons are damaged, 2 indicates that approximately $60 \%$ of the neurons are damaged, and 3 indicates that $100 \%$ of the neurons are damaged. Each hemisphere was evaluated independently by an examiner blinded to the experimental conditions.

2.5. Assessment of CBF and Cerebral $\mathrm{PO}_{2}$. A $100 \mu \mathrm{m}$ diameter thermocouple and two $230 \mu \mathrm{m}$ fibers were attached to the oxygen probe. This combined probe measured oxygen, temperature, and microvascular blood flow. These measurements required OxyLite and Oxyflo instruments. OxyLite 2000 (Oxford Optronix Ltd., Oxford, UK) is a 2-channel device (measuring $\mathrm{PO}_{2}$ and temperature at two sites simultaneously), whereas OxyFlo 2000 is a 2-channel laser doppler perfusion monitoring instrument. Under anesthesia, the mouse was placed in a stereotaxic apparatus and the combined probe was implanted in to the brain (or the hypothalamus) using the atlas and coordinates of Paxinos and Watson [21].

2.6. Extracellular Levels of Glutamate, Lactate-to-Pyruvate Ratio, Glycerol, $\mathrm{NO}_{x}{ }^{-}$, and 2,3-DHBA in the Hypothalamus. Hypothalamic samples were homogenized in $0.05 \mathrm{M}$ phosphate buffer, pH7.0 and then centrifuged at $4000 \times \mathrm{g}$ for $20 \mathrm{~min}$ at $4^{\circ} \mathrm{C}$. The supernatants were used for determination of cellular levels of glutamate, lactate-to-pyruvate ratio, glycerol, $\mathrm{NO}_{x}{ }^{-}$, and 2,3-DHBA. The dialysis probe (4 $\mathrm{mm}$ in length CMA/12; Carnegie Medicine, Stockholm, Sweden) was put into the supernatants to obtain the dialysates.

The nitric oxide $\left(\mathrm{NO}_{x}{ }^{-}\right)$concentration in the dialysates of hypothalamus was measured with the Eicom ENO-20 $\mathrm{NO}_{x}{ }^{-}$analysis system [22]. In the Eicom ENO-20 $\mathrm{NO}_{x}{ }^{-}$ analysis system, after the $\mathrm{NO}_{2}{ }^{-}$and $\mathrm{NO}_{3}{ }^{-}$in the sample have been separated by the column, the $\mathrm{NO}_{2}{ }^{-}$reacts in the acidic solution with the primary aromatic amine to produce an azo compound. Following this, the addition of aromatic amines to the azo compound results in a coupling that produces a diazo compound and the absorbance rate of the red color in this compound is then measured. For measurement of glutamate, lactate-to-pyruvate ratio, and glycerol, the dialysates were injected into a CMA600 microdialysis analyzer (Carnegie Medicine, Stockholm, Sweden). The concentrations of hydroxyl radicals were measured by a 
modified procedure based on the hydroxylation of sodium salicylates by hydroxyl radicals, leading to the production of 2,3-dihydroxybenzoic acid and 2,5-dihydroxybenzoic acid [12].

2.7. Determination of Lipid Peroxidation. Lipid peroxidation was assessed by measuring the levels of MDA with 2thiobarbituric acid (TBA) to form a chromophore absorbing at $532 \mathrm{~nm}$ [23]. About $0.1 \mathrm{~g}$ of tissue was homogenized with $1.5 \mathrm{~mL}$ of $0.1 \mathrm{M}$ phosphate buffer at $\mathrm{pH} 3.5$. The reaction mixture $(0.2 \mathrm{~mL}$ of sample, $1.5 \mathrm{~mL}$ of $20 \%$ acetic acid, $0.2 \mathrm{~mL}$ of $8.1 \%$ sodium dodecyl sulfate, and $1.5 \mathrm{~mL}$ of aqueous solution of $0.8 \% \mathrm{TBA}$, up to $4 \mathrm{~mL}$ with distilled water) was heated to $95^{\circ} \mathrm{C}$ for $1 \mathrm{~h}$, and then $5 \mathrm{~mL}$ of $\mathrm{N}$-butanol and pyridine $(15: 1 \mathrm{vol} / \mathrm{vol})$ was added. The mixture was vortexed vigorously, centrifuged at $1500 \mathrm{~g}$ for $10 \mathrm{~min}$, and the absorbance of the organic phase was measured at $532 \mathrm{~nm}$. The values were expressed as nanomoles of TBA-reactive substances (MDA equivalent) per milligram of protein.

2.8. Quantification of Total and Oxidized Glutathione. Tissues were homogenized in 5\% 5-eslfoslicylic acid (1:10 wt/vol) at $0^{\circ} \mathrm{C}$, and the supernatants were used for analysis of total and oxidized glutathione. Total glutathione [reduced-form glutathione $(\mathrm{GSH})+$ oxidized-form glutathione (GSSG)] was analyzed according to the Tieze method [24], and GSSG was determined as described by Griffith [25]. The recycling assay for total glutathione is oxidized by 5,5-Dithiosis [2 acid] (DTNB) to give GSSG with stoichiometric formation of 5-thio-2-nitrobenzoic acid. GSSG is reduced to GSH by the action of the highly specific glutathione reductase (GR) and nicotinamide adenine dinucleotide phosphate (reduced form; NADPH). The rate of 5-thio-2-nitrobenzoic acid formation is followed at $412 \mathrm{~nm}$ and is proportional to the sum of GSH and GSSG present.

2.9. Determination of Glutathione Peroxidase $\left(G P_{x}\right)$ and Glutathione Reductase (GR) Activity. Tissues were homogenized in $0.05 \mathrm{M}$ phosphate buffer, pH7.0 and then centrifuged at $4000 \times \mathrm{g}$ for $20 \mathrm{~min}$ at $4^{\circ} \mathrm{C}$. The supernatants were used for $\mathrm{GP}_{x}$ and GR activity assay. The $\mathrm{GP}_{x}$ and GR activities were assayed with a commercial $\mathrm{GP}_{x}$ assay kit (Sigma, USA) and a GP assay kit (Sigma, USA), respectively. One unit of $\mathrm{GP}_{x}$ and GR activity was defined as the amount of sample required to oxidize $1 \mathrm{mmol}$ of $\mathrm{NADPH}$ per minute based on the molecular absorbance of $6.22 \times 10^{6}$ for NADPH.

2.10. Plasma Concentrations of Inflammatory and Intracellular Adhesion Molecules and Cytokines. Blood samples were taken at 4 hours after the start of heat exposure for determination of TNF- $\alpha$, IL-10, and intercellular adhesion molecule ${ }^{-1}$ (ICAM-1) levels. The amounts of the cytokines in serum were determined by double antibody sandwich enzymelinked immunosorbent assay ( $R \& D$ systems, Minneapolis, $\mathrm{MN}$ ) according to the manufacturer's instructions. Optical densities were read on a plate reader set at $450 \mathrm{~nm}$ for TNF$\alpha$, IL-10, and ICAM-1. The concentration of TNF- $\alpha$, IL-10, and ICAM-1 in the serum samples was calculated from the standard curve multiplied by the dilution factor and was expressed as picograms per milliliter [15].

2.11. Plasma Assessment of ACTH and Corticosterone. Plasma ACTH and corticosterone were assayed using ACTH (Rat, Mouse)-RIA kit (Phoenix Pharmaceuticals, Burlingame, CA, USA) and Corticosterone Double Antibody RIA kit (MP Biomedicals, Solon, OH, USA), respectively. All analyses were performed according to manufacturers' instructions.

2.12. Statistical Analysis. All values in the figures and text are expressed as mean \pm S.E.M. of $n$ observations, where $\mathrm{n}$ represents the number of animals studied. Statistical evaluation was performed by using analysis of variance (ANOVA) followed by a multiple-comparison test (Scheffe's test). The Kaplan Meier analysis was used for determining the significant differences in the survival rate between control and drug-treated groups. The Wilcoxon tests were used for evaluation of neuronal damage scores. The Wilcoxon test converts the scores or values of a variable to ranks, requires calculation of a sum of the ranks, and provides critical values for the sum necessary to test the null hypothesis at a given significant levels. These data were presented as "median", followed by first (Q1) and third (Q3) quartile. A $P$ value of less than 0.05 was considered to be statistically significant.

\section{Results}

3.1. Thermoregulatory Outcome and Lethality Induced by $W B H$. Functional tests showed balanced thermoregulatory deficits between vehicle-treated $\mathrm{WBH}$ group and $\mathrm{CD} 34^{+}$ cells-treated $\mathrm{WBH}$ mice. $\mathrm{CD}^{+} 4^{+}$cells-treated $\mathrm{WBH}$ mice showed significant $(P<0.05, n=12$ /group) improvement of functional recovery on thermoregulatory test at $4-16 \mathrm{~h}$ compared with vehicle-treated WBH mice (Figure 1). The survival of $\mathrm{CD} 34^{+}$-treated $\mathrm{WBH}$ mice was 12 of 12 mice and one of 12 for vehicle-treated WBH mice (Figure 1).

3.2. Hypothalamic Cells Damage Induced by WBH. Histological verification showed that hypothalamic values of cell damage score (Table 1, Figure 2) for vehicle-treated $\mathrm{WBH}$ mice were significantly higher $4 \mathrm{~h}$ after $\mathrm{WBH}$ than they were for the non-WBH control mice. Vehicle-treated WBH mice displayed cell body shrinkage, pyknosis of the nucleus, loss of Nissl substance, and disappearance of the nucleolus (Figure 2). As compared to non-WBH control mice, vehicletreated WBH mice also had significantly higher levels of a cellular damage marker (e.g., glycerol) (Table 2) in the hypothalamus $[26,27]$. $\mathrm{CD} 34^{+}$cells-treated $\mathrm{WBH}$ mice showed significant improvement of hypothalamic cell damage (Tables 1 and 2).

3.3. Hypothalamic Ischemia and Hypoxia Induced by WBH. Intracerebral assessment revealed that hypothalamic levels of both $\mathrm{CBF}$ and PO2 for vehicle-treated heated mice were significantly lower at $4 \mathrm{~h}$ after $\mathrm{WBH}$ than they were for 


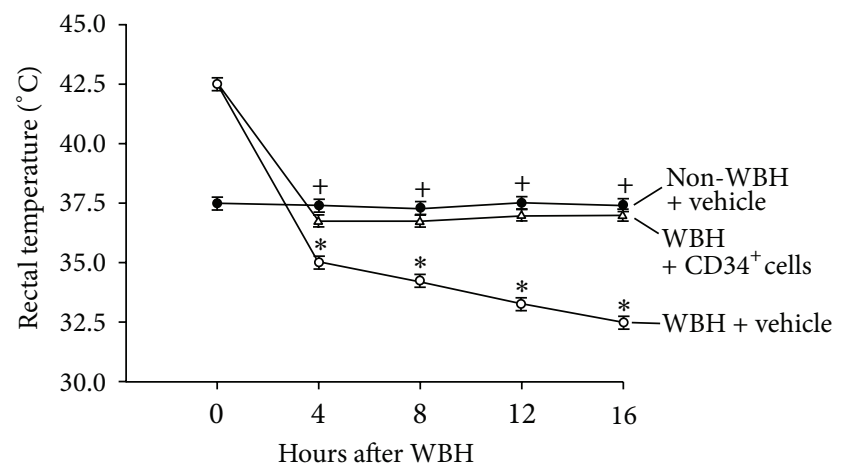

(a)

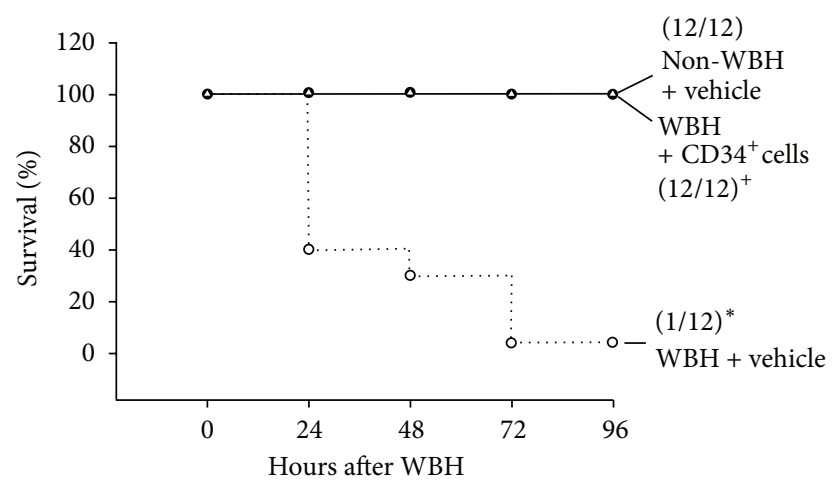

(b)

FIGURE 1: Thermoregulatory deficits and lethality by WBH. (a) Thermoregulatory dysfunction (or animals become hypothermia when exposing them to room temperature, $26^{\circ} \mathrm{C}$ ) caused by whole body heating ( $\mathrm{WBH} ; 41.2^{\circ} \mathrm{C}$ for $\left.1 \mathrm{~h}\right)$. Data are expressed as means \pm S.E.M. of 12 mice per group. *At time " 0 " $\mathrm{h}$ after WBH (or immediately after the termination of $\mathrm{WBH}$ ), heated mice treated with vehicle ( $\mathrm{WBH}+$ vehicle; "O") or heated mice treated with $\mathrm{CD} 34^{+}$cells $\left(\mathrm{WBH}+\mathrm{CD} 34^{+}\right.$cells; “ $\triangle$ ") had significantly higher rectal temperature $\left(\sim 42.5^{\circ} \mathrm{C}\right)$ than those of non-WBH mice treated with vehicle (non-WBH + vehicle; “๑”). In contrast, at time " 4 " $h$, " 8 " h, "12" h, or "16" h after WBH, (WBH + vehicle) group had significantly lower rectal temperature (Tco; $\sim 35^{\circ} \mathrm{C}-\sim 32.5^{\circ} \mathrm{C}$ ) than those of (non-WBH + vehicle) group. ${ }^{+}$At time " 4 " $h$, " 8 " $h$, " 12 " $h$, or " 16 " $\mathrm{h}$ after $\mathrm{WBH},\left(\mathrm{WBH}+\mathrm{CD} 34^{+}\right.$cells) group had significantly higher rectal temperature than those of $(\mathrm{WBH}+$ vehicle) group $(P<0.01)$. (b) Lethality (or decreased percentage survival) caused by $\mathrm{WBH} .{ }^{*} P<0.01$, (non-WBH + vehicle) mice versus $(\mathrm{WBH}+$ vehicle) mice. ${ }^{+} P<0.01$, (WBH $+\mathrm{CD} 34^{+}$cells) group versus $(\mathrm{WBH}$ + vehicle) group.

the non-WBH mice (Table 2). Again, the hypothalamic levels of cellular ischemia markers (e.g., glutamate and lactate/pyruvate ratio) $[26,27]$ for vehicle-treated $\mathrm{WBH}$ mice were significantly higher at $4 \mathrm{~h}$ after $\mathrm{WBH}$ than they were for the non-WBH control mice (Table 2). WBH mice treated with $\mathrm{CD} 34^{+}$cells showed significant improvement of cerebral ischemia and hypoxia (Table 2).

3.4. Oxidative Stress Induced by WBH. Biochemical determination showed that hypothalamic levels of MDA, GSSG/GSH, $\mathrm{NO}_{x}{ }^{-}$, and 2,3-DHBA for vehicle-treated WBH mice were all significantly higher at $4 \mathrm{~h}$ after $\mathrm{WBH}$ than they were for the non-WBH control mice (Table 3). On the other hand, hypothalamic levels of $\mathrm{GP}_{x}$ and GR for vehicle-treated $\mathrm{WBH}$ mice were significantly lower than they were for the nonWBH control mice (Table 3 ). WBH mice treated with $\mathrm{CD}^{2} 4^{+}$ cells showed significant improvement of oxidative stress caused by WBH (Table 3).

\subsection{Increased Plasma Levels of both ACTH and Corticosterone} Induced by $W B H$. Biochemical verification showed that plasma levels of both ACTH and corticosterone for vehicletreated $\mathrm{WBH}$ mice were significantly higher $4 \mathrm{~h}$ after $\mathrm{WBH}$ than they were for the non-WBH control mice (Table 4). WBH mice treated with $\mathrm{CD} 34^{+}$cells showed significant enhancement of both ACTH and corticosterone in plasma by WBH (Table 4).

3.6. Increased Serum Levels of Systemic Inflammatory Response Indicator Induced by $W B H$. Biochemical determination showed that serum levels of several systemic inflammatory response indicators such as TNF- $\alpha$ and ICAM-1 for vehicletreated heated mice were significantly higher $4 \mathrm{~h}$ after $\mathrm{WBH}$ than they were for the non-WBH mice (Table 4). WBH mice treated with $\mathrm{CD} 34^{+}$cells showed significant reduction of the increased serum levels of these 2 inflammatory response indicators by WBH (Table 4). Table 4 also demonstrated that the serum levels of an anti-inflammatory cytokine, IL-10, were further significantly increased following $\mathrm{CD}_{3}{ }^{+}$cells therapy.

\section{Discussion}

Heat tolerance varies considerably among individuals [28]. When exposed to a certain extent of heat exposure, some subjects display a slightly elevated body core temperature (Tco < $40^{\circ} \mathrm{C}$ ) while others become severely ill with a Tco above $40^{\circ} \mathrm{C}$. When rats are exposed to heat, they also show a wide interindividual variability [9]. Heat tolerant rats showing the lowest Tco had a highest plasma ACTH and corticosterone levels. Conversely, heat intolerant rats exhibiting the highest Tco had the lowest plasma ACTH and corticosterone. These investigators also provide data to promote that decreased heat tolerance is associated with HPA axis impairment in rats. Consisting with the above hypothesis, we showed that vehicle-treated $\mathrm{WBH}$ mice exhibiting lowest survival showed the lowest plasma ACTH and corticosterone levels. In contrast, $\mathrm{CD} 34^{+}$cells-treated $\mathrm{WBH}$ mice presented a greater percentage survival as well as a greater plasma level of both ACTH and corticosterone. The mobilization of HPA axis activity is associated with the increase in blood ACTH and corticosterone concentrations $[7,8]$. In addition, our previous results have shown that corticosterone supplementation has beneficial effects in treating heatstroke in rats [28]. It is likely that CD34+ cells therapy may improve heat tolerance by attenuating HPA axis impairment in mice during heat exposure.

Accumulating evidence has demonstrated that $\mathrm{CD} 34^{+}$ cells transplantation is a promising therapeutic method against cerebral ischemic diseases, such as stroke, traumatic brain injury, and spinal cord injury $[11,13,14]$. Our previous 
TABLE 1: Effects of heat exposure on neuronal damage score of the brain (or the hypothalamus) in different groups of mice.

\begin{tabular}{lr}
\hline Treatment groups & Neuronal damage score $(0-3)$ \\
\hline (1) Non-WBH mice & $0(0,0)$ \\
(2) Non-WBH mice treated with CD34 ${ }^{+}$cells $\left(1 \times 10^{5}\right.$ cells $/ 0.3 \mathrm{~mL}$, i.v. $)$ & $0(0,0)$ \\
(3) Heated mice treated with vehicle saline $(0.3 \mathrm{~mL}$, i.v. $)$ & $2(2,2)^{\mathrm{a}}$ \\
(4) Heated mice treated with CD34 ${ }^{+}$cells $\left(1 \times 10^{5}\right.$ cells $/ 0.3 \mathrm{~mL}$, i.v. $)$ & $0.75(0,0.75)^{\mathrm{b}}$ \\
\hline
\end{tabular}

Samples were measured 4 hours after whole body heating (WBH; $41.2^{\circ} \mathrm{C}$ for 1 houer) or the equivalent time period for non-heated group. ${ }^{\mathrm{a}}$ compared with non-

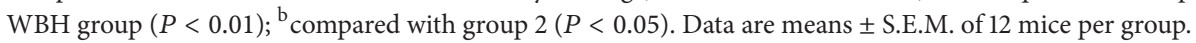

TABLE 2: Effects of heat exposure on hypothalamic levels of glutamate, lactate/pyruvate, glycerol, cerebral blood flow $(\mathrm{CBF})$, and $\mathrm{PO} \mathrm{O}_{2}$ in different groups of mice.

\begin{tabular}{|c|c|c|c|c|c|}
\hline Treatment groups & $\begin{array}{c}\text { Glutamate } \\
\text { (percentage of } \\
\text { baseline) }\end{array}$ & $\begin{array}{l}\text { Lactate/pyruvate } \\
\text { ratio }\end{array}$ & $\begin{array}{c}\text { Glycerol } \\
\text { (percentage of } \\
\text { baseline) }\end{array}$ & $\mathrm{CBF}(\mathrm{BPU})$ & $\mathrm{PO}_{2}(\mathrm{mmHg})$ \\
\hline (1) Non-WBH mice & $98 \pm 5$ & $10 \pm 4$ & $99 \pm 6$ & $328 \pm 23$ & $21 \pm 2$ \\
\hline $\begin{array}{l}\text { (2) Non-WBH mice treated with CD34 } \\
\text { cells }\left(1 \times 10^{5} \text { cells } / 0.3 \mathrm{~mL} \text {, i.v. }\right)\end{array}$ & $100 \pm 6$ & $12 \pm 5$ & $98 \pm 7$ & $307 \pm 24$ & $21 \pm 3$ \\
\hline $\begin{array}{l}\text { (3) Heated mice treated with vehicle } \\
\text { saline }(0.3 \mathrm{~mL} \text {, i.v. })\end{array}$ & $196 \pm 22^{\mathrm{a}}$ & $231 \pm 32^{\mathrm{a}}$ & $198 \pm 16^{\mathrm{a}}$ & $162 \pm 11^{\mathrm{a}}$ & $10 \pm 1^{\mathrm{a}}$ \\
\hline $\begin{array}{l}\text { (4) Heated mice treated with } \mathrm{CD} 34^{+} \text {cells } \\
\left(1 \times 10^{5} \text { cells } / 0.3 \mathrm{~mL} \text {, i.v. }\right)\end{array}$ & $142 \pm 10^{b}$ & $77 \pm 11^{b}$ & $66 \pm 12^{b}$ & $245 \pm 16^{\mathrm{b}}$ & $16 \pm 2^{\mathrm{b}}$ \\
\hline
\end{tabular}

Samples were measured 4 hours after whole body heating (WBH) or the equivalent time period for non-heated group. ${ }^{\text {a }}$ compared with non-WBH group $(P<$

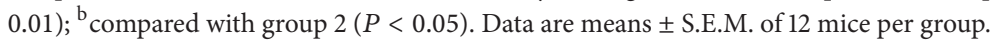

TABLE 3: Effect of heat exposure on hypothalamic levels of malondialdehyde (MDA), oxidative-form glutathione (GSSG)/reduced-form glutathione $(\mathrm{GSH})$, glutathione peroxidase $\left(\mathrm{GP}_{x}\right)$, glutathione reductase $(\mathrm{GR})$, nitric oxide metabolites $\left(\mathrm{NO}_{x}{ }^{-}\right)$, and 2,3-dihydroxy benzoic acid (2,3-DHBA) in different groups of mice.

\begin{tabular}{|c|c|c|c|c|c|c|}
\hline Treatment groups & $\begin{array}{c}\text { MAD } \\
(\mathrm{nmol} / \mathrm{mg} \text { protein })\end{array}$ & GSSG/GSH & $\begin{array}{c}\text { GP } \\
(\mathrm{mU} / \mathrm{mg} \text { protein })\end{array}$ & $\begin{array}{c}\text { GR } \\
(\mathrm{mu} / \mathrm{mg} \text { protein })\end{array}$ & $\mathrm{NO}_{x}^{-}(\mu \mathrm{M})$ & $\begin{array}{c}\text { 2,3-DHBA } \\
\text { (percentage of } \\
\text { baseline) }\end{array}$ \\
\hline (1) Non-WBH mice & $5 \pm 2$ & $0.45 \pm 0.14$ & $314 \pm 36$ & $175 \pm 16$ & $19 \pm 2$ & $100 \pm 6$ \\
\hline $\begin{array}{l}\text { (2) Non-WBH mice treated with } \\
\mathrm{CD} 4^{+} \text {cells }\end{array}$ & $4 \pm 2$ & $0.42 \pm 0.16$ & $302 \pm 33$ & $169 \pm 17$ & $17 \pm 3$ & $99 \pm 5$ \\
\hline $\begin{array}{l}\text { (3) WBH mice treated with } \\
\text { vehicle saline }\end{array}$ & $12 \pm 2^{\mathrm{a}}$ & $2.43 \pm 0.38^{\mathrm{a}}$ & $83 \pm 17^{\mathrm{a}}$ & $81 \pm 13^{\mathrm{a}}$ & $115 \pm 12^{\mathrm{a}}$ & $188 \pm 10^{\mathrm{a}}$ \\
\hline $\begin{array}{l}\text { (4) } \mathrm{WBH} \text { mice treated with } \\
\mathrm{CD} 34^{+} \text {cells }\end{array}$ & $4 \pm 2^{\mathrm{b}}$ & $0.42 \pm 0.15^{\mathrm{b}}$ & $257 \pm 28^{\mathrm{b}}$ & $166 \pm 15^{\mathrm{b}}$ & $21 \pm 4$ & $103 \pm 5^{b}$ \\
\hline
\end{tabular}

Samples were measured 4 hours after whole body heating (WBH; $41.2^{\circ} \mathrm{C}$ for 1 hour) or the equivalent period for non-WBH. ${ }^{\mathrm{a}}$ compared with non-WBH group $(P<0.01)$; ${ }^{\mathrm{b}}$ compared with group $2(P<0.05)$. Data are means \pm S.E.M. of 12 mice per group.

TABLE 4: Effect of heat exposure on plasma levels of adrenocorticotrophic hormone (ACTH), corticosterone, tumor necrosis factor- $\alpha$ (TNF$\alpha$ ), interleukin-10 (IL-10), and ICAM-1 for various groups of mice.

\begin{tabular}{|c|c|c|c|c|c|}
\hline Treatment groups & $\begin{array}{c}\text { ACTH } \\
\left(\mathrm{pg} \cdot \mathrm{mL}^{-1}\right)\end{array}$ & $\begin{array}{l}\text { Corticosterone } \\
\left(\mathrm{ng} \cdot \mathrm{mL}^{-1}\right)\end{array}$ & $\begin{array}{c}\text { TNF } \\
(\mathrm{pg} / \mathrm{mL})\end{array}$ & $\begin{array}{c}\text { IL-10 } \\
\text { (pg/mL) }\end{array}$ & $\begin{array}{l}\text { ICAM } \\
(\mathrm{pg} / \mathrm{mL})\end{array}$ \\
\hline (1) Non-WBH mice & $372 \pm 79$ & $32 \pm 19$ & $10 \pm 6$ & $5 \pm 3$ & $9 \pm 4$ \\
\hline (2) Non-WBH mice treated with $\mathrm{CD} 34^{+}$cells & $361 \pm 72$ & $29 \pm 17$ & $8 \pm 5$ & $6 \pm 2$ & $11 \pm 5$ \\
\hline (3) WBH mice treated with saline & $601 \pm 98^{\mathrm{a}}$ & $256 \pm 25^{\mathrm{a}}$ & $415 \pm 82^{\mathrm{a}}$ & $11 \pm 4^{\mathrm{a}}$ & $496 \pm 22^{\mathrm{a}}$ \\
\hline (4) $\mathrm{WBH}$ mice treated with $\mathrm{CD} 34^{+}$cells & $1764 \pm 116^{\mathrm{b}}$ & $643 \pm 30^{\mathrm{b}}$ & $37 \pm 6^{\mathrm{b}}$ & $83 \pm 11^{\mathrm{b}}$ & $67 \pm 18^{\mathrm{b}}$ \\
\hline
\end{tabular}

Samples were measured 4 hours after whole body temperature $\left(\mathrm{WBH} ; 41.2^{\circ} \mathrm{C}\right.$ for 1 hour) or the equivalent time period for non-WBH group. ${ }^{\mathrm{a}}$ compared with non-WBH group $(P<0.01)$; ${ }^{\mathrm{b}}$ compared with group $2(P<0.01)$. Data are means \pm S.E.M. of 12 mice per group. 


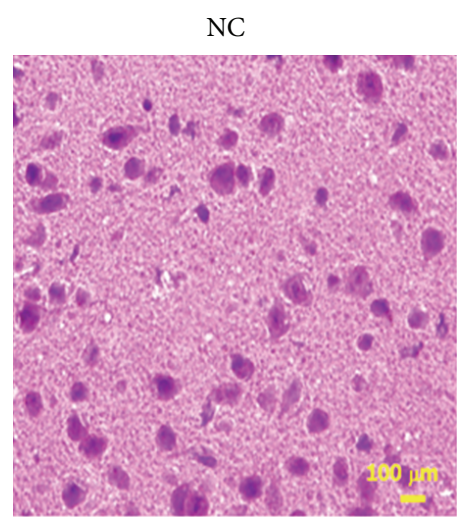

(a)

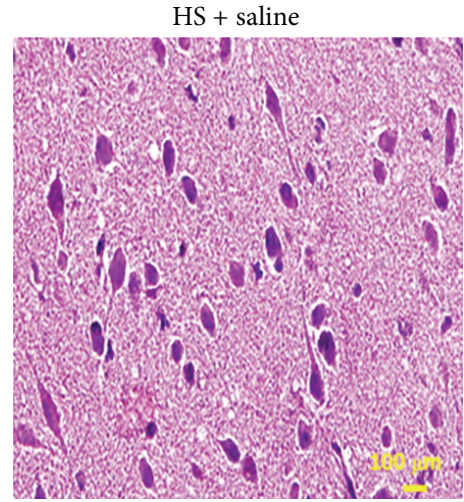

(b)

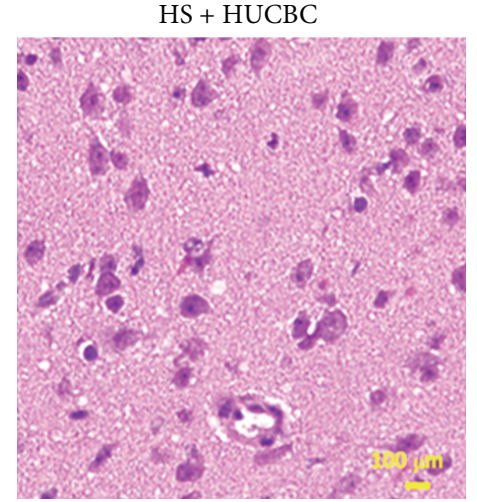

(c)

FIGURE 2: Hypothalamic hematoxylin-eosin (HE) staining 4 hours after WBH. Photographs showing hypothalamic HE staining for a (non$\mathrm{WBH}+$ vehicle $), \mathrm{a}(\mathrm{WBH}+$ vehicle $)$ mouse, and a (WBH $+\mathrm{CD}^{+} 4^{+}$cells) mouse. Samples were obtained 4 hours after WBH for the WBH groups or the equivalent time period for the non-WBH group. (WBH + vehicle) mice showed cell body shrinkage, pyknosis of the nucleus, loss of Nissl substance, and disappearance of the nucleolus which could be attenuated by CD $34^{+}$cells treatment.

[12] and present results have also shown that HUCBCderived $\mathrm{CD} 34^{+}$cells therapy has beneficial effects in heatstroke. Severe heat stress decreases mean arterial pressure (MAP), increases intracranial pressure (ICP), and results in decreased cerebral perfusion pressure $(\mathrm{CPP}=\mathrm{MAP}-\mathrm{ICP})$, which leads to cerebral ischemia and hypoxia [18]. In addition, hypothalamic and plasma values of cellular ischemia and damage markers, prooxidant enzymes, proinflammatory cytokines, inducible nitric oxide synthase-dependent nitric oxide, and myeloperoxidase activity were all significantly elevated after heatstroke occurrence [18].

In particular, heatstroke causes overproduction of proinflammatory cytokines in both the brain and the peripheral blood stream; this is associated with decreased MAP. In fact, activated inflammation is involved in the severity of acute heart failure [29], septic shock [30], and circulatory shock [31]. Systemic administration of interleukin-1 receptor [32] or glucocorticoids [28] immediately after the onset of heatstroke is able to attenuate arterial hypotension and cerebral ischemia and injury and to improve survival. In an anesthetized rat model of heatstroke, $\mathrm{CD} 34^{+}$cell therapy significantly attenuates arterial hypotension, intracranial hypertension, cerebral ischemia, hypoxia, and injury, and TNF- $\alpha$ overproduction during heatstroke [33]. In order to avoid the influence of anesthetic state, our data further demonstrate that in an unanesthetized mouse model of heatstroke, CD $34^{+}$cells therapy promotes survival by attenuating overproduction of systemic inflammatory response molecules (e.g., TNF- $\alpha$ and ICAM-1) and ischemic, hypoxic, and oxidative damage to the hypothalamus. In fact, both anti-inflammatory and proinflammatory cytokines normally have a role to fight infection and prevent immune pathology, respectively [34]. Interleukin-10 has important anti-inflammatory and immunosuppressive properties through attenuation of TNF$\alpha$ and other proinflammatory cytokines [31]. Thus, it appears that $\mathrm{CD} 34^{+}$therapy may improve brain inflammation during heatstroke by stimulating production of IL-10.

An occurrence of local inflammation process may be considered since TNF- $\alpha$ mRNA decreased in the tolerant rats' hypothalamus and pituitary as compared with control rats [9]. On the contrary, the occurrence of higher stimulation by free radicals led to an increase in the TNF- $\alpha$ mRNA level in the heat exhausted rats. $[9,35]$. Heat tolerant rats exhibit low IL- $1 \beta$ and TNF- $\alpha$ mRNAs as well as high corticosterone levels, whereas heat exhausted rats present high IL-1 $\beta$ and TNF- $\alpha$ mRNA, but low corticosterone level [9]. As shown in Figure 1, animals displayed hyperthermia immediately after termination of WBH. Four hours after WBH, vehicle-treated WBH mice showed activated inflammation, hypothalamic ischemia, and HPA axis impairment, which could be significantly attenuated by $\mathrm{CD} 34^{+}$cells therapy.

As compared to heated mice treated with vehicle solution, heated mice treated with $\mathrm{CD} 34^{+}$cells displayed lower hypothalamic values of cellular ischemia (e.g., glutamate and lactate-to-pyruvate ratio), damage (e.g., glycerol) markers, and prooxidant enzymes (e.g., lipid peroxidation and glutathione oxidation). In contrast, CD34+ cells-treated heated mice had higher hypothalamic values of antioxidant defences (e.g., glutathione peroxidase and glutathione reductase). These observations suggest that heat-induced oxidative damage to hypothalamus in mice can be attenuate by $\mathrm{CD} 34^{+}$cells therapy.

\section{Conclusion}

Heatstroke is characterized by excessive hyperthermia associated with systemic inflammatory responses, which leads to multiple organ failure, in which brain disorders predominates. This definition can be almost fulfilled by our present animal model $[26,36]$. Heatstroke mice displayed (i) systemic inflammation; (ii) ischemic, hypoxic, and oxidative damage to the hypothalamus; (iii) hypothalamic-pituitaryadrenocortical axis impairment; (iv) decreased survival; and (v) thermoregulatory deficit. These heatstroke reactions can be significantly attenuated by HUCBC-derived $\mathrm{CD} 34^{+}$cells therapy. Our data suggest that $\mathrm{CD} 34^{+}$cells therapy may improve heat tolerance by reducing systemic inflammation and HPA axis impairment in heatstroke mice. 


$\begin{array}{ll}\text { Abbreviations } \\ \text { WBH: } & \text { Whole body heating } \\ \text { HUCBC: } & \text { Hypothalamic-pituitary-adrenal } \\ \text { ACTH: } & \text { Adrenocorticotropic hormone } \\ \text { NO }_{x}{ }^{-}: & \text {Nitric oxide metabolites } \\ 2,3-\mathrm{DHBA}: & 2,3 \text {-dihydroxybenzoic acid } \\ \text { GSSG: } & \text { Oxidative-form glutathione } \\ \text { GSH: } & \text { Reduced-form glutathione } \\ \text { GP } x: & \text { Glutathione peroxidase } \\ \text { GR: } & \text { Glutathione reductase } \\ \text { CBF: } & \text { Cerebral blood flow } \\ \text { ICAM-1: } & \text { Intercellular adhesion molecule-1 } \\ \text { MDA: } & \text { Malondialdehyde } \\ \text { TBA: } & \text { 2-Thiobarbituric acid } \\ \text { TNF- } \alpha: & \text { Tumor necrosis factor-alpha } \\ \text { IL-10: } & \text { Interleukin-10 } \\ \text { IL-1 } \beta: & \text { Interleukin-1 } \beta \text {. }\end{array}$

\section{Ethical Approval}

The animals and research protocols used in this study followed the guidelines of the Ethical Committee for Use of Animals of Chi Mei Medical Center (Tainan, Taiwan) and national law and policies of the National Science Council of China (Taipei, Taiwan). All efforts were made to minimize the number of animals used and their suffering.

\section{Conflict of Interests}

The authors declare that there is no conflict of interests regarding the publication of this paper.

\section{Acknowledgment}

The work was supported in parts by the grants from the National Science Council of China: Grant nos. NSC97-2321B-384-001-MY2 and NSC99-2314-B-384-005-MY3.

\section{References}

[1] M. T. Lin, Y. L. Yang, and H. T. Tsay, "C-fos expression in rat brain during heat stress," The Journal of Thermal Biology, vol. 24, no. 5-6, pp. 423-427, 1999.

[2] H. R. Lieberman, J. H. Georgelis, T. J. Maher, and S. K. Yeghiayan, "Tyrosine prevents effects of hyperthermia on behavior and increases norepinephrine," Physiology \& Behavior, vol. 84, no. 1, pp. 33-38, 2005.

[3] M. T. Lin, "Heatstroke-induced cerebral ischemia and neuronal damage," Annals of the New York Academy of Sciences, vol. 813, pp. 572-580, 1997.

[4] C.-K. Chang, W.-T. Chiu, C.-P. Chang, and M.-T. Lin, "Effect of hypervolaemic haemodilution on cerebral glutamate, glycerol, lactate and free radicals in heatstroke rats," Clinical Science, vol. 106, no. 5, pp. 501-509, 2004.

[5] J. L. Cham, R. Klein, N. C. Owens, M. Mathai, M. McKinley, and E. Badoer, "Activation of spinally projecting and nitrergic neurons in the PVN following heat exposure," American Journal of Physiology: Regulatory Integrative and Comparative Physiology, vol. 291, no. 1, pp. R91-R101, 2006.
[6] H.-J. Tsay, H.-Y. Li, C.-H. Lin, Y.-L. Yang, J.-Y. Yeh, and M.-T. Lin, "Heatstroke induces c-fos expression in the rat hypothalamus," Neuroscience Letters, vol. 262, no. 1, pp. 41-44, 1999.

[7] M. Cure, "Plasma corticosterone response in continuous versus discontinuous chronic heat exposure in rat," Physiology \& Behavior, vol. 45, no. 6, pp. 1117-1122, 1989.

[8] J. Djordjević, G. Cvijić, and V. Davidović, "Different activation of ACTH and corticosterone release in response to various stressors in rats," Physiological Research, vol. 52, no. 1, pp. 6772, 2003.

[9] V. Michel, A. Peinnequin, A. Alonso, A. Buguet, R. Cespuglio, and F. Canini, "Decreased heat tolerance is associated with hypothalamo-pituitary-adrenocortical axis impairment," Neuroscience, vol. 147, no. 2, pp. 522-531, 2007.

[10] I. D. Lewis, "Clinical and experimental uses of umbilical cord blood," Internal Medicine Journal, vol. 32, no. 12, pp. 601-609, 2002.

[11] J. Chen, P. R. Sanberg, Y. Li et al., "Intravenous administration of human umbilical cord blood reduces behavioral deficits after stroke in rats," Stroke, vol. 32, no. 11, pp. 2682-2688, 2001.

[12] S.-H. Chen, F.-M. Chang, Y.-C. Tsai, K.-F. Huang, and M.-T. Lin, "Resuscitation from experimental heatstroke by transplantation of human umbilical cord blood cells," Critical Care Medicine, vol. 33, no. 6, pp. 1377-1383, 2005.

[13] D. Lu, P. R. Sanberg, A. Mahmood et al., "Intravenous administration of human umbilical cord blood reduces neurological deficit in the rat after traumatic brain injury," Cell Transplantation, vol. 11, no. 3, pp. 275-281, 2002.

[14] S. Saporta, J.-J. Kim, A. E. Willing, E. S. Fu, C. D. Davis, and P. R. Sanberg, "Human umbilical cord blood stem cells infusion in spinal cord injury: engraftment and beneficial influence on behavior," Journal of Hematotherapy \& Stem Cell Research, vol. 12, no. 3, pp. 271-278, 2003.

[15] W.-S. Liu, C.-T. Chen, N.-H. Foo et al., "Human umbilical cord blood cells protect against hypothalamic apoptosis and systemic inflammation response during heatstroke in rats," Pediatrics \& Neonatology, vol. 50, no. 5, pp. 208-216, 2009.

[16] S. Chatterjee, S. Premachandran, R. S. Bagewadikar, S. Bhattacharya, S. Chattopadhyay, and T. B. Poduval, "Arginine metabolic pathways determine its therapeutic benefit in experimental heatstroke: role of Th1/Th2 cytokine balance," Nitric Oxide: Biology and Chemistry, vol. 15, no. 4, pp. 408-416, 2006.

[17] S. Chatterjee, S. Premachandran, D. Sharma, R. S. Bagewadikar, and T. B. Poduval, "Therapeutic treatment with L-arginine rescues mice from heat stroke-induced death: physiological and molecular mechanisms," Shock, vol. 24, no. 4, pp. 341-347, 2005.

[18] S. H. Chen, M. T. Lin, and C. P. Chang, "Ischemic and oxidative damage to the hypothalamus may be responsible for heat stroke," Current Neuropharmacology, vol. 11, no. 2, pp. 129-140, 2013.

[19] Z.-C. Chen, W.-S. Wu, M.-T. Lin, and C.-C. Hsu, "Protective effect of transgenic expression of porcine heat shock protein 70 on hypothalamic ischemic and oxidative damage in a mouse model of heatstroke," BMC Neuroscience, vol. 10, article 111, 2009.

[20] W. A. Pulsinelli, D. E. Levy, and T. E. Duffy, "Regional cerebral blood flow and glucose metabolism following transient forebrain ischemia," Annals of Neurology, vol. 11, no. 5, pp. 499-502, 1982.

[21] G. Paxinos and C. Watson, The Rat Brain in Stereotaxic Coordinates, Academic Press, New York, NY, USA, 1986. 
[22] H. Togashi, K. Mori, K. Ueno et al., "Consecutive evaluation of nitric oxide production after transient cerebral ischemia in the rat hippocampus using in vivo brain microdialysis," Neuroscience Letters, vol. 240, no. 1, pp. 53-57, 1998.

[23] J.-L. Wang, D.-S. Ke, and M.-T. Lin, "Heat shock pretreatment may protect against heatstroke-induced circulatory shock and cerebral ischemia by reducing oxidative stress and energy depletion," Shock, vol. 23, no. 2, pp. 161-167, 2005.

[24] F. Tietze, "Enzymic method for quantitative determination of nanogram amounts of total and oxidized glutathione: applications to mammalian blood and other tissues," Analytical Biochemistry, vol. 27, no. 3, pp. 502-522, 1969.

[25] O. W. Griffith, "Determination of glutathione and glutathione disulfide using glutathione reductase and 2-vinylpyridine," Analytical Biochemistry, vol. 106, no. 1, pp. 207-212, 1980.

[26] C.-K. Chang, C.-P. Chang, W.-T. Chiu, and M.-T. Lin, "Prevention and repair of circulatory shock and cerebral ischemia/injury by various agents in experimental heatstroke," Current Medicinal Chemistry, vol. 13, no. 26, pp. 3145-3154, 2006.

[27] S.-H. Hsiao, C.-P. Chang, T.-H. Chiu, and M.-T. Lin, "Resuscitation from experimental heatstroke by brain cooling therapy," Resuscitation, vol. 73, no. 3, pp. 437-445, 2007.

[28] C.-C. Liu, C.-H. Chien, and M.-T. Lin, "Glucocorticoids reduce interleukin- $1 \beta$ concentration and result in neuroprotective effects in rat heatstroke," The Journal of Physiology, vol. 527, part 2, pp. 333-343, 2000.

[29] T. Nakamura, S. Suzuki, C. Ushiyama, N. Shimada, and H. Koide, "Effect of phosphodiesterase III inhibitor on plasma concentrations of endothelin-1 and tumour necrosis factor in patients with acute heart failure," Acta Cardiologica, vol. 57, no. 1, pp. 19-21, 2002.

[30] W. J. Schirmer, J. M. Schirmer, and D. E. Fry, "Recombinant human tumor necrosis factor produces hemodynamic changes characteristic of sepsis and endotoxemia," Archives of Surgery, vol. 124, no. 4, pp. 445-448, 1989.

[31] A. Oberholzer, C. Oberholzer, and L. L. Moldawer, "Cytokine signaling-regulation of the immune response in normal and critically ill states," Critical Care Medicine, vol. 28, supplement 4, pp. N3-N12, 2000.

[32] M. T. Lin, H. H. Liu, and Y. L. Yang, "Involvement of interleukin1 receptor mechanisms in development of arterial hypotension in rat heatstroke," American Journal of Physiology: Heart and Circulatory Physiology, vol. 273, no. 4, part 2, pp. H2072-H2077, 1997.

[33] S.-H. Chen, F.-M. Chang, H.-K. Chang, W.-C. Chen, K.-F. Huang, and M.-T. Lin, "Human umbilical cord blood-derived $\mathrm{CD} 34^{+}$cells cause attenuation of multiorgan dysfunction during experimental heatstroke," Shock, vol. 27, no. 6, pp. 663-671, 2007.

[34] K. W. Moore, R. de Waal Malefyt, R. L. Coffman, and A. O'Garra, "Interleukin-10 and the interleukin-10 receptor," Annual Review of Immunology, vol. 19, pp. 683-765, 2001.

[35] V. C. Jongeneel, "Regulation of the TNF- $\alpha$ gene," Progress in clinical and biological research, vol. 388, pp. 367-381, 1994.

[36] A. Bouchama and J. P. Knochel, "Heat stroke," The New England Journal of Medicine, vol. 346, no. 25, pp. 1978-1988, 2002. 

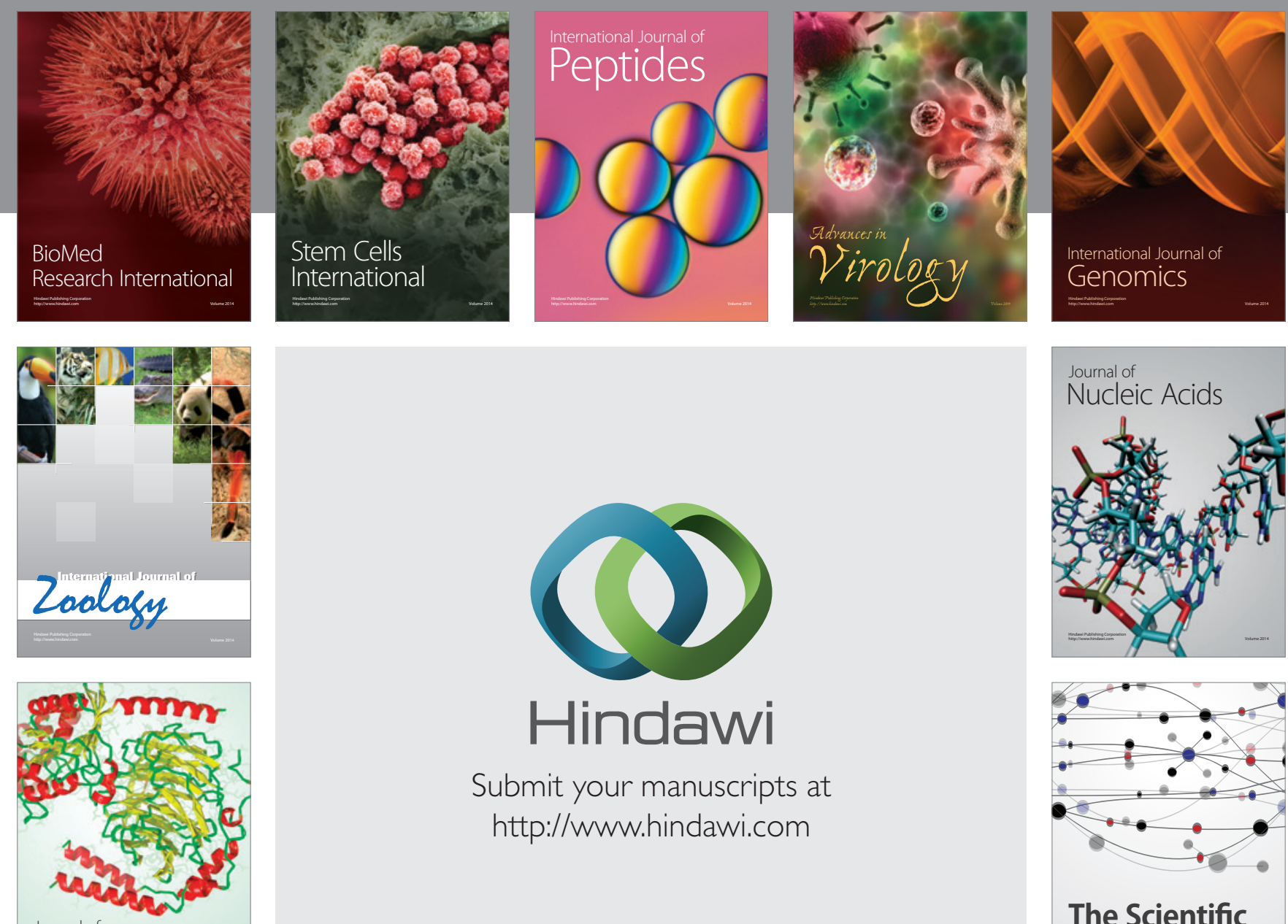

Submit your manuscripts at

http://www.hindawi.com

Journal of
Signal Transduction
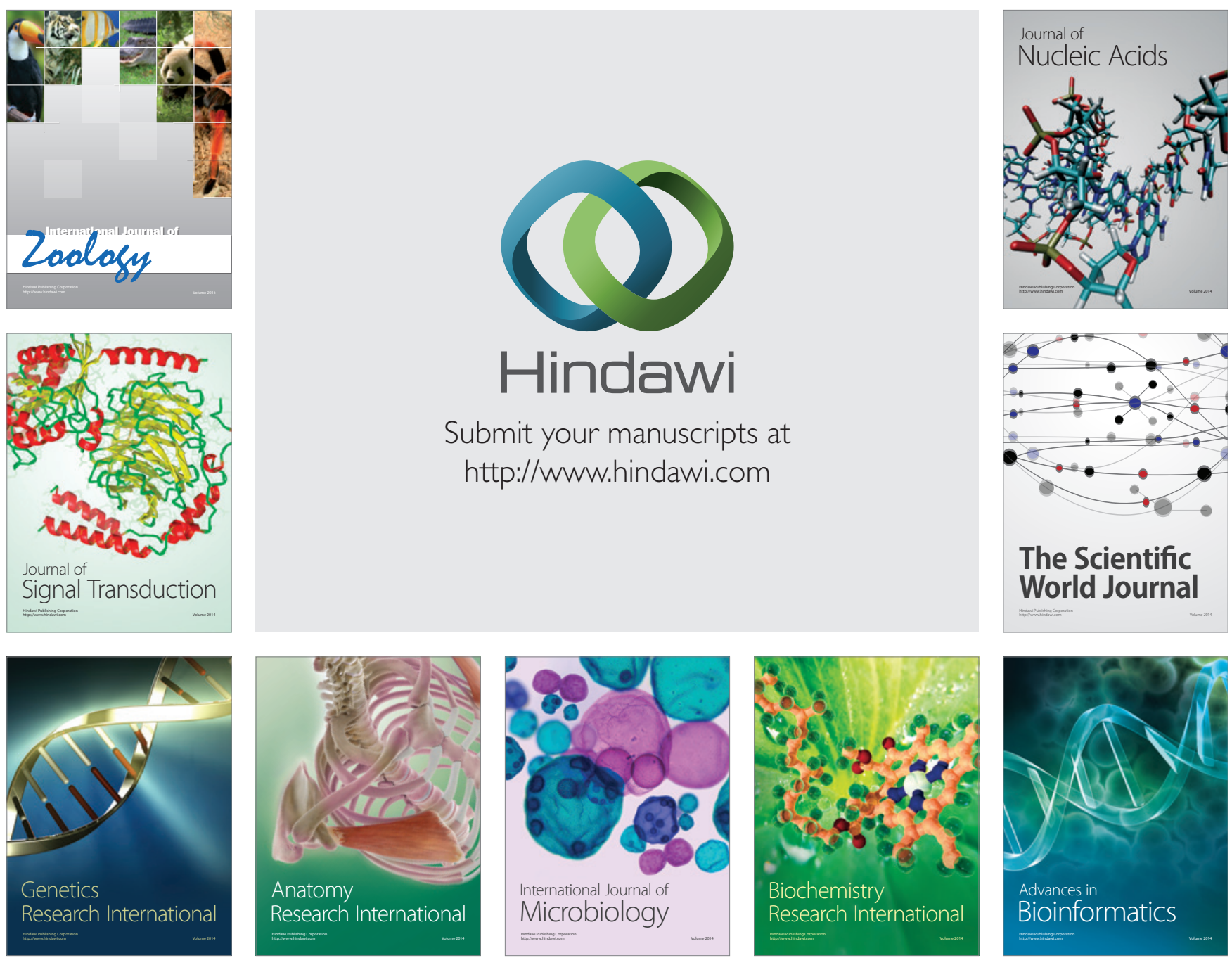

The Scientific World Journal
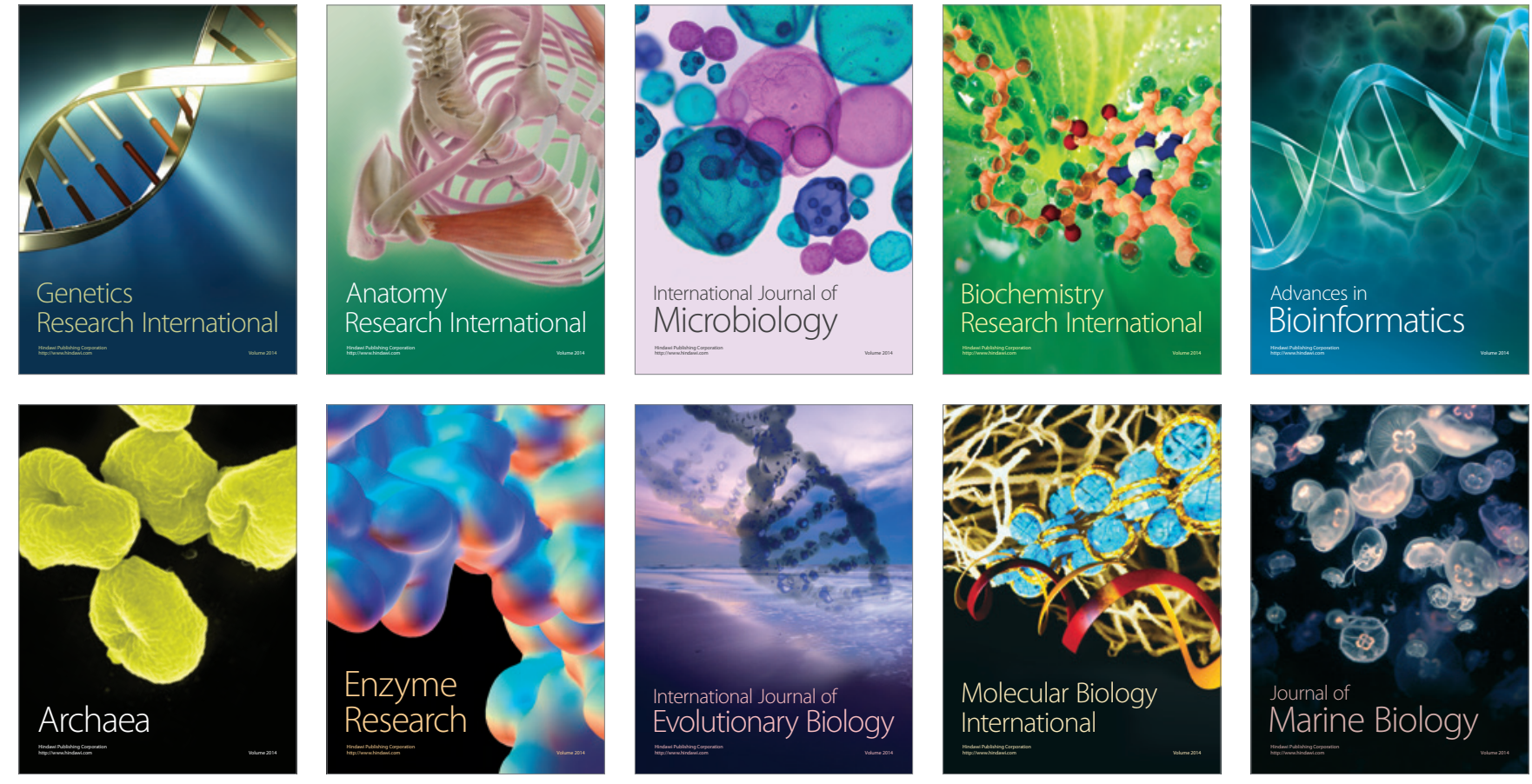